\title{
LACTOBACILLUS REUTERI - AN ALTERNATIVE IN THE FIRST-LINE OF HELICOBACTER PYLORI ERADICATION
}

\author{
CĂTĂLINA MIHAI ${ }^{1}$, BOGDAN MIRCEA MIHAI ${ }^{2} *$, MIHAELA DRANGA ${ }^{1}$, ANCA \\ CARDONEANU $^{3}$, CRISTINA CIJEVSCHI PRELIPCEAN ${ }^{1}$
}

\author{
${ }^{I}$ Institute of Gastroenterology and Hepatology, "Grigore T. Popa" University of Medicine and Pharmacy, "Sf. Spiridon" \\ Clinical Hospital, Iași, Romania \\ ${ }^{2}$ Clinical Centre of Diabetes, Nutrition and Metabolic Disease, "Grigore T. Popa" University of Medicine and Pharmacy, \\ "Sf. Spiridon" Clinical Hospital, Iași, Romania \\ ${ }^{3}$ Rheumatology, "Grigore T. Popa" University of Medicine and Pharmacy, Rehabilitation Clinical Hospital, Iași, Romania
}

*corresponding author: bogdanmihai@yahoo.com

Manuscript received: March 2018

\begin{abstract}
In the context of reduced effectiveness of classical antibiotic regimens in eradicating Helicobacter pylori infection, it is justified to search for alternative therapies. The present study included 70 patients diagnosed with Helicobacter pylori infection by the rapid urease test, randomized into two therapeutic regimens: Lactobacillus reuteri DSMZ17648, liquorice and calcium carbonate and classical proton pump inhibitor - amoxicillin - clarithromycin scheme. The eradication efficiency was $54.3 \%$ in the Lactobacillus reuteri group $v s 77.1 \%$ in the antibiotic group $(\mathrm{p}=0.042)$ but with a significantly lower rate of side effects $(2.9 \%$ vs $17.1 \%, \mathrm{p}=0.037)$. Finding new drugs to eradicate Helicobacter pylori with increased efficacy, costeffectiveness ratio and no side effects remains a challenge.
\end{abstract}

\section{Rezumat}

În condițiile reducerii eficacităţii schemelor clasice cu antibiotice în eradicarea infecției cu Helicobacter pylori, este justificată preocuparea pentru terapii noi. Studiul de față a inclus 70 de pacienți diagnosticați prin testul rapid ureazic cu infecție cu Helicobacter pylori, randomizați în două regimuri terapeutice: Lactobacillus reuteri, extract de lemn dulce și carbonat de calciu și schema clasică cu inhibitor de pompă de protoni - amoxicilină - claritromicină. Eficiența eradicării a fost de 54,3\% în grupul tratat cu Lactobacillus reuteri comparativ cu 77,1\% în grupul tratat cu antibiotice $(\mathrm{p}=0,042)$, dar cu o rată semnificativ mai mică de efecte secundare $(2,9 \%$ vs $17,1 \%, \mathrm{p}=0,037)$. Găsirea de noi medicamente în eradicarea Helicobacter pylori cu eficacitate crescută, cost-eficiente și fără efecte secundare rămâne în continuare un deziderat.

Keywords: Helicobacter pylori, eradication, antibiotic resistance, Lactobacillus reuteri

\section{Introduction}

It is estimated that $50 \%$ of the globe population is infected with Helicobacter pylori (H. pylori) with variations between $20 \%$ and $80 \%$, the prevalence being higher in emerging economies compared to those developed $[1,2]$. In Romania, the $H$. pylori infection prevalence is about $70 \%$ of the adult population [3]. $H$. Pylori is involved in the pathogenesis of numerous digestive disorders and is considered as a risk factor for gastric cancer [4]. Indications for the eradication of $H$. pylori infection include: gastritis, peptic ulcer, MALT lymphoma, H. pylori positive dyspepsia, longterm treatment with non-steroidal anti-inflammatory drugs, antiaggregants or anticoagulants, proton pump inhibitors (PPI), iron deficiency anaemia, B12 vitamin deficiency, idiopathic thrombocytopenia (for the last three indications other causes must be excluded first) [5]. H. pylori infection eradication is a continuing challenge. Commonly, the eradication regimen includes PPI associated with two antibiotics: clarithromycin and amoxicillin or metronidazole with a therapy duration of 7, 10, up to 14 days. This regimen known as "legacy therapy", even though still widely used as first-line therapy, has a low efficiency as a result of global growth of microbial resistance to clarithromycin and metronidazole $[6,7]$. Therefore, most current guidelines recommend as first-line of eradication approach the quadruple concomitant therapy or 14-day bismuth quadruple therapy $[5,8,9]$. Prolonged duration and multiple antibiotic treatment is shadowed by intestinal microbiota damage and a series of side effects that often decrease compliance and cause treatment discontinuation. New drugs, with different mechanisms of action, seek their place as first-line therapy or as associate to classic therapy with antibiotics in the $H$. pylori eradication: probiotics, metabiotics, bacteriophages, bacteriocins, in association with the study of microorganism and host genetic particularities [10, 11].

In recent years, evidences have accumulated suggesting that $H$. pylori could be eradicated from the stomach through selective intercellular interactions by some 
FARMACIA, 2019, Vol. 67, 5

particular Lactobacillus strains [12]. Lactobacillus reuteri ( $L$. reuteri) strains have been identified as $H$. pylori binding high specificity antagonists. L. reuteri has been shown to inhibit through competition $H$. pylori binding to a series of so-called glycolipid receptors. Mukai et al. examined the competition of binding of $L$. reuteri and $H$. pylori to gangliotetraosylceramide (asialo-GM1) and sulphatide which are putative glycolipid receptor molecules of $H$. pylori, and identified a possible sulphatide-binding protein of the L. reuteri strains [13]. In order to identify a strain of $L$. reuteri with the highest specificity for H. pylori, Organobalance $\mathrm{GmbH}$, Berlin, Germany, selected from hundreds of Lactobacillus strains, $L$. reuteri DSMZ17648. The study has shown that they are capable of forming a stable co-aggregate with $H$. pylori in an acid environment similar to gastric acid. Co-aggregation occurred within a few seconds after contacting the two strains, flow cytometry indicating that each $L$. reuteri DSMZ17648 cell binds 2-3 $H$. pylori cells [14]. These co-aggregates are subsequently eliminated, reducing the colonization of the gastric mucosa with $H$. pylori without affecting the normal intestinal flora [10]. Moreover, it has been desired to create a biologically inactive strain that retains its aggregation properties without being influenced by the antibiotic treatment, a fact done biotechnologically by spray-dye and lyophilisation [15]. Results of clinical trials using the L. reuteri DSMZ 17648 strain in $H$. pylori eradication are still contradictory [16]. In this regard, the association of $L$. Reuteri DSMZ17648 with deglycyrrhizinated liquorice extract and calcium carbonate seems to be a promising tool against $H$. pylori. It has been also proved that the extract of liquorice roots inhibit the adhesion of $H$. pylori to human gastric mucosa [17]. The purpose of our study was to compare the classic eradication scheme (PPI, clarithromycin, amoxicillin) with the association between L. Reuteri DSMZ17648, deglycyrrhizinated liquorice extract and calcium carbonate as the first line treatment in eradicating $H$. pylori infection.

\section{Materials and Methods}

The prospective randomized study was conducted over one year (2017) in a tertiary gastroenterology centre in Romania. All patients signed the informed consent and the study was approved by the local Ethics Committee.

Inclusion criteria

We enrolled adult treatment-naive patients with dyspeptic symptoms, who underwent upper digestive endoscopy, diagnosed with $H$. pylori infection and had H. pylori eradication indication. Diagnosis of H. pylori infection was made by rapid urease test, with two biopsies taken: one of the antrum and one of the gastric body.

\section{Exclusion criteria}

Patients treated with PPI, bismuth or antibiotics in the last month, patients with upper digestive bleeding, neoplastic disease, pregnancy and breastfeeding, patients with contraindications to any of the drugs used in eradication schemes (e.g: infection with Clostridium difficile, known antibiotic allergies) and patients that followed previously any $H$. pylori treatment regimen were excluded.

\section{Patient management}

Patients were randomized 1:1 in two groups: group A (STT) received esomeprasole (20 mg bid) - clarithromycin (500 mg bid) - amoxicillin (1000 mg bid) standard triple therapy for 10 days and group B (L. reuteri) received esomeprasole $20 \mathrm{mg}$ bid and the association between L. Reuteri DSMZ17648, deglycyrrhizinated liquorice extract and calcium carbonate, $1 \mathrm{cps}$ bid for 14 days. All patients were re-evaluated 6 weeks after therapy by $H$. pylori mono-clonal stool antigen test. The registered parameters were: demographic data (age, sex), diagnosis based on upper digestive endoscopy, presence of comorbidities, eradication efficiency and the presence of side effects in the two types of therapies.

\section{Outcome}

The primary endpoint was $H$. pylori eradication 6 weeks after completion of therapy. The secondary endpoint was the development of adverse effects to the therapy used.

Statistical analysis

The database was consisted using SPSS 18.0 application. The dispersion analysis of the dependent variable intra and intergroup was performed using ANOVA test. The significant difference between two or more groups depending on the distribution of the series of values for a significance threshold of $95 \%$ for the quantitative variables was assessed using: the tStudent test - parametric test which compares the average values registered in two groups with normal distributions and the test $\chi^{2}$ - nonparametric test which compares 2 or more frequency repartitions coming from the same population, applied when the expected results exclude one another; $p$-value $<0.05$ was considered significant. The ROC curve - draws the balance specificity/sensitiveness as a prognosis factor.

\section{Results and Discussion}

The study included 70 patients, aged between 26 and 72 , assigned as follows: 35 patients in the STT group and 35 patients in $L$. reuteri group with a slight predominance of female gender $(55.71 \%)$. The indication for $H$. pylori infection eradication was in the order of frequency: functional dyspepsia (28/70 - 40\%), gastritis $(26 / 70-37.14 \%)$, duodenal ulcer $(11 / 70$ $15.71 \%)$ and gastric ulcer (5/70 - 7.14\%). 16 patients (22.85\%) experienced comorbidities and concomitant treatments for associated conditions: 5 cases of diabetes 
FARMACIA, 2019, Vol. 67, 5

mellitus, 4 cases of cardiac pathology, 3 cases of liver pathology, 2 cases of chronic kidney disease, 1 case of rheumatoid arthritis, 1 case of psychiatric pathology. The presence of comorbidities induced an estimated

risk of treatment failure of 1.68 times higher $(\mathrm{RR}=1.86$; IC95\%: 1.01 - 2.95). There were no statistically significant differences between the clinical parameters of the two studied groups (Table I).

Table I

Characteristics of patients in the two studied groups

\begin{tabular}{|l|c|c|c|}
\hline Characteristics & STT $(\mathrm{n}=35)$ & L. reuteri $(\mathrm{n}=35)$ & $\mathrm{p}$-value \\
\hline $\begin{array}{l}\text { Average age } \pm \text { SD } \\
(\text { min - max) }\end{array}$ & $\begin{array}{c}48.37 \pm 12.84 \\
(26-72)\end{array}$ & $\begin{array}{c}51.74 \pm 10.85 \\
(27-72)\end{array}$ & 0.240 \\
\hline Age & $9(25.7 \%)$ & $4(11.4 \%)$ & 0.291 \\
$\quad<40, \mathrm{n}(\%)$ & $20(57.1 \%)$ & $23(65.7 \%)$ & \\
$\quad 40$ - 60, n (\%) & $6(17.1 \%)$ & $8(22.9 \%)$ & \\
$\quad>60, \mathrm{n}(\%)$ & $16(45.7 \%)$ & $15(42.9 \%)$ & 0.810 \\
\hline Male, $\mathrm{n}(\%)$ & $19(54.3 \%)$ & $20(57.1 \%)$ & \\
Female, $\mathrm{n}(\%)$ & $13(37.1 \%)$ & $15(42.9 \%)$ & 0.723 \\
\hline Functional dyspepsia & $12(34.3 \%)$ & $14(40.0 \%)$ & \\
Gastritis & $3(8.6 \%)$ & $2(5.7 \%)$ & \\
Gastric ulcer & $7(20.0 \%)$ & $4(11.4 \%)$ & \\
Duodenal ulcer & $7(20.0 \%)$ & $9(25.7 \%)$ & 0.569 \\
\hline Comorbidities, $\mathrm{n}(\%)$ & $27(77.1 \%)$ & $19(54.3 \%)$ & $\mathbf{0 . 0 4 2}$ \\
\hline Treatment success, $\mathrm{n}(\%)$ & $6(17.1 \%)$ & $1(2.9 \%)$ & $\mathbf{0 . 0 3 7}$ \\
\hline Side effects, $\mathrm{n}(\%)$ & \multicolumn{2}{|}{}
\end{tabular}

The success of $H$. pylori eradication was higher in the antibiotic treated group $(77.1 \%$ intention-to-treat and $81.81 \%$ per-protocol) compared to $L$. reuteri treated $(54.3 \%, p=0.042)$. In contrast, side effects (nausea, abdominal pain, abdominal bloating, diarrhoea) were significantly more common in the STT-treated group $(17.1 \%$ vs $2.9 \%, \mathrm{p}=0.037)$, causing discontinuation in 2 cases (both due to diarrhoea). In the L. reuteri - treated group, only one patient reported morning vomiting, during the first days of treatment. The risk of side effects was 1.86 times higher in patients treated with antibiotics (RR = 1.86; IC95\%: 1.24 - 2.79). The side effects were associated with an estimated 2.37-fold greater treatment failure rate $(\mathrm{RR}=2.37$; IC95\%: 1.30 - 4.32).

Table II

Treatment success $v s$ failure based on clinical parameters

\begin{tabular}{|c|c|c|c|c|c|c|}
\hline \multirow[t]{2}{*}{ Characteristics } & \multicolumn{3}{|c|}{$\operatorname{STT}(n=35)$} & \multicolumn{3}{|c|}{ L. reuteri $(\mathrm{n}=35)$} \\
\hline & Success $(n=27)$ & Failure $(\mathrm{n}=8)$ & p-value & Success $(n=19)$ & Failure $(n=16)$ & p-value \\
\hline $\begin{array}{l}\text { Average age } \pm \text { SD } \\
(\text { min-max })\end{array}$ & $\begin{array}{c}50.48 \pm 12.81 \\
(28-72) \\
\end{array}$ & $\begin{array}{c}41.25 \pm 10.79 \\
(26-53) \\
\end{array}$ & 0.074 & $\begin{array}{c}50.37 \pm 9.92 \\
(27-69) \\
\end{array}$ & $\begin{array}{c}53.38 \pm 11.98 \\
(31-72) \\
\end{array}$ & 0.422 \\
\hline $\begin{array}{l}\text { Age } \\
\\
<40 \text { year-old, } \mathrm{n}(\%) \\
\\
40-60 \text { year-old, } \mathrm{n}(\%) \\
>60 \text { year-old, } \mathrm{n}(\%)\end{array}$ & $\begin{array}{c}6(22.2 \%) \\
15(55.6 \%) \\
6(22.2 \%)\end{array}$ & $\begin{array}{c}3(37.5 \%) \\
5(62.5 \%) \\
0(0.0 \%)\end{array}$ & 0.159 & $\begin{array}{c}2(10.5) \\
14(73.7) \\
3(15.8 \%)\end{array}$ & $\begin{array}{c}2(12.5) \\
9(56.3) \\
3(31.3 \%)\end{array}$ & 0.511 \\
\hline $\begin{array}{l}\text { Male, } \mathrm{n}(\%) \\
\text { Female, } \mathrm{n}(\%)\end{array}$ & $\begin{array}{l}12(44.4 \%) \\
15(55.6 \%)\end{array}$ & $\begin{array}{l}4(50.0 \%) \\
4(50.0 \%)\end{array}$ & 0.782 & $\begin{array}{c}7(36.8 \%) \\
12(63.6 \%)\end{array}$ & $\begin{array}{l}8(50.0 \%) \\
8(50.0 \%)\end{array}$ & 0.433 \\
\hline Functional dyspepsia, n (\%) & $9(33.3 \%)$ & $4(50.0 \%)$ & 0.397 & $11(57.0 \%)$ & $4(25.0 \%)$ & 0.047 \\
\hline Gastritis, $\mathrm{n}(\%)$ & $10(37.1 \%)$ & $2(25.0 \%)$ & 0.521 & $7(36.8 \%)$ & $7(43.8 \%)$ & 0.678 \\
\hline Gastric ulcer, n (\%) & $2(7.4 \%)$ & $1(12.5 \%)$ & 0.664 & $0(0.0 \%)$ & $2(12.5 \%)$ & 0.070 \\
\hline Duodenal ulcer, n (\%) & $6(22.2 \%)$ & $1(12.5 \%)$ & 0.529 & $1(5.3 \%)$ & $3(18,8 \%)$ & 0.266 \\
\hline Comorbidities, n (\%) & $3(11.1 \%)$ & $4(50.0 \%)$ & 0.024 & $3(15.8 \%)$ & $6(37.5 \%)$ & 0.142 \\
\hline
\end{tabular}

Analysing the success rate of treatment in each group we observed that STT treatment failure was statistically associated with the presence of comorbidities, while the best results of $L$. reuteri treatment were recorded in patients with functional dyspepsia (Table II).

The ROC curve shows that, compared to antibiotic treatment, the success of $L$. reuteri treatment was influenced in a proportion of $76.6 \%$ by the younger age $(\mathrm{AUC}=0.766$; IC95\%: $0.570-0.961), 61.3 \%$ by the type of associated medical condition (functional dyspepsia) (AUC = 0.613; IC95\%: 0.362 - 0.864) and
$60.3 \%$ by the lack of comorbidities (AUC $=0.603$; IC95\%: 0.313 - 0.812) (Figure 1). In patients less than 50 years of age with functional dyspepsia and without comorbidities the success of $H$. pylori eradication with $L$. reuteri was $87.5 \%$.

The triple therapy with clarithromycin remains the most prescribed $H$. pylori infection eradication scheme [18]. In our study, $H$. pylori eradication with STT was $77.1 \%$, comparable to other Romanian and European studies $[19,20]$. Two other studies published in Romania showed the increase in the effectiveness 
of triple PPI-amoxicillin-clarithromycin therapy by using the double dose of PPI or extending the duration of treatment to 14 days [21, 22]. In recent years, there has been an increase in antibiotic resistance, especially in clarithromycin, which leads to a decrease in eradication efficiency below $80 \%$ [9, 23]. In our country there is very little data on primary resistance to antibiotics used in the first line to eradicate $H$. pylori infection [21].

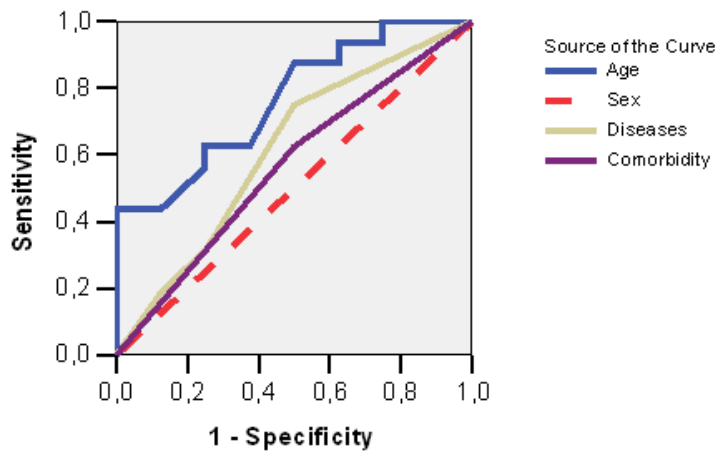

Figure 1.

L. reuteri treatment success rate (ROC curve, balance of clinical data sensitivity/specificity)

In our study we used an association of L. reuteri DSMZ17648 $100 \mathrm{mg}$, with extract of deglycyrrhizinated liquorice $75 \mathrm{mg}$ (protects the gastric mucosa from the corrosive action of gastric acid, helps in its regeneration and has an anti $H$. pylori action) and calcium carbonate $80 \mathrm{mg}$ (antacid action). L. reuteri DSMZ17648 is technologically processed and stabilized so as to form co-aggregates with $H$. pylori and not to affect other components of the intestinal flora. In the study group, eradication with $L$. reuteri associated with PPI was $54.3 \%$. Our data are consistent with other studies that demonstrated the effectiveness of $L$. reuteri in eradicating $H$. pylori infection. Multiple studies have shown a decrease in ${ }^{13} \mathrm{C}$ UBT values in $H$. pylori positive patients receiving $L$. reuteri $\mathrm{DSMZ}$ 17648 compared to placebo [14, 15, 24]. In addition, Borodin's study demonstrated an improvement in clinical symptoms and histology in patients treated with L. reuteri DSMZ17648 [24]. Saggioro et al. obtained in a randomized placebo-controlled trial on $30 \mathrm{H}$. pylori-positive dyspeptic patients a $60 \%$ eradication rate in positive group $v s 0 \%$ with placebo. The group was treated with $40 \mathrm{mg}$ omeprazole and $L$. reuteri $1.6 \times 10^{6} \mathrm{CFU} /$ day, bid, pre-prandial for 30 days [25]. In contrast, Dore et al. in an open study on $21 \mathrm{H}$. pylori confirmed patients showed that treatment with L. reuteri $2 \times 10^{8} \mathrm{CFU}$ and pantoprazole $40 \mathrm{mg} /$ day, for 60 days eradicated H. pylori in just $14.2 \%$ of patients [26]. The differences between the results obtained in this study and the previous one were considered by the authors generated on the basis of distinct geographic areas with different $H$. pylori strains, possible differences between the L. reuteri strains used, doses, timing and duration of administration. Results similar to our study were also reported in the pediatric population: $50 \%$ eradication with $L$. reuteri DSMZ17648 $200 \mathrm{mg} /$ day administration vs 68.75\% in the antibiotic-treated group [27]. Another promising approach is the addition of $L$. reuteri strains to antibiotic treatment, which leads to increased rates of eradication and side effects minimization [28, 29]. This approach has not been the subject of our study and requires further research. The good results of H. pylori eradication in our study could have more explanations. First, L. reuteri was given as capsules rather than tablets. The compressive force required to obtain a tablet is very high and there are significant structural alterations of the ingredients of cellular origin [30]. Secondly, unlike other studies with $L$. reuteri, the drug was administered before meals, thus favouring optimal contact between $L$. reuteri and $H$. pylori. Third, the association with extract of deglycyrrhizinated liquorice and calcium carbonate seems to increase the efficacy of L. reuteri.

An important issue in the eradication of $H$. pylori is patient compliance, which is largely affected by side effects related to the antibiotic therapy used. In our study, side effects were statistically significantly more present in the STT group (17.1\%), leading to premature discontinuation of treatment in 2 cases compared to L. reuteri group. The frequency of side effects in the classic eradication scheme is similar to the data published in the literature [5]. There are many other studies in the literature which highlight the good tolerability and lack of side effects in patients treated with L. reuteri [14-16, 27-29].

In our study, treatment with $L$. reuteri seems more effective in young patients with functional dyspepsia and without comorbidities (eradication rate more than $80 \%$ ), regardless of sex, but larger patient trials are needed to confirm this data.

\section{Conclusions}

L. reuteri in association with extract of deglycyrrhizinated liquorice and calcium carbonate may be an alternative to the classic antibiotic regimen in eradicating $H$. pylori infection in treatment-naive patients. L. reuteri has been successful in eradicating H. pylori in over $50 \%$ of patients, with very good tolerability and compliance. Future studies, on larger study groups, are needed in order to include alternative therapies to classic antibiotic regimens in $H$. pylori infection management.

\section{Conflict of interest}

The authors declare no conflict of interest. 


\section{References}

1. Hooi JKY, Lai WY, Ng WK, Suen MMY, Underwood FE, Tanyingoh D, Malfertheiner P, Graham DY, Wong VWS, Wu JCY, Chan FKL, Sung JJY, Kaplan GG, $\mathrm{Ng}$ SC, Global Prevalence of Helicobacter pylori Infection: Systematic Review and Meta-Analysis. Gastroenterology, 2017; 153(2): 420-429.

2. Diaconescu S, Miron I, Gimiga N, Olaru C, Ioniuc I, Ciongradi I, Sarbu I, Stefanescu G, Unusual endoscopic findings in children: Esophageal and Gastric Polyps Three Cases Report. Medicine, 2016; 95(3): e2539: 1-4.

3. Sporea I, Popescu A, van Blankenstein M, Sirli R, Focşea M, Dănilă M, The prevalence of Helicobacter pylori infection in Western Romania. Rom $J$ Gastroenterol., 2003; 12: 15-18.

4. Matran IM, Farcas A, Bojita M, Dumitrascu DL, Alternative therapies in gastric hypersecretion. Farmacia, 2017; 65(3): 323-328.

5. Malfertheiner P, Megraud F, O'Morain CA, Gisbert JP, Kuipers EJ, Axon AT, Bazzoli F, Gasbarrini A, Atherton J, Graham DY, Hunt R, Moayyedi P, Rokkas T, Rugge M, Selgrad M, Suerbaum S, Sugano K, ElOmar EM, European Helicobacter and Microbiota Study Group and Consensus panel, Management of Helicobacter pylori infection - the Maastricht V/ Florence Consensus Report. Gut, 2016; 0: 1-25.

6. Megraud F, Coenen S, Versporten A, Kist M, LopezBrea M, Hirschl AM, Andersen LP, Goossens H, Glupczynski Y, Study Group participants, Helicobacter pylori resistance to antibiotics in Europe and its relationship to antibiotic consumption. Gut, 2013; 62: 34-42.

7. Boyanova L, Gergova G, Estatiev I, Spassova Z, Kandilarov N, Yaneva P, Markovska R, Mitov I, Helicobacter pylori resistance to six antibiotics by two breakpoint systems and resistance evolution in Bulgaria. Infect Dis (Lond.), 2016; 48: 56-62.

8. Fallone CA, Chiba N, van Zanten SV, The Toronto Consensus for the Treatment of Helicobacter pylori Infection in Adults. Gastroenterology, 2016; 151: 51-69.

9. Chey WD, Leontiadis GI, Howden CW, Moss SF, ACG Clinical Guideline: Treatment of Helicobacter pylori Infection. Am J Gastroenterol., 2017; 112: 212-238.

10. Baryshnikova NV, Uspenskiy YP, Suvorov AN, Eradication of Helicobacter Pylori Infection: Past, Present, and Future. J Clin Gastroenterol Treat, 2016; 2: 011.

11. Diaconescu S, Stanca R, Bolat M, Olaru C, Gimiga N, Fatu-Vascu AM, Stefanescu G, Ciubotariu G, Ioniuc I, Iorga M, Burlea M, Updates in epidemiology and prevention of Helicobacter pylori infection. Rom J Oral Rehabilit., 2016; 8(3): 40-47.

12. Tyagi AK, Prasad S, Commentary: probiotic and technological properties of Lactobacillus spp. strains from the human stomach in the search for potential candidates against gastric microbial dysbiosis. Front Microbiol., 2015; 6: 433.

13. Mukai T, Asasaka T, Sato E, Mori K, Matsumoto M, Ohori $\mathrm{H}$, Inhibition of binding of Helicobacter pylori to the glycolipid receptors by probiotic Lactobacillus reuteri. FEMS Immunol Med Microbiol., 2002; 32: 105-110.

14. Holz C, Busjahn A, Significant Reduction in Helicobacter pylori Load in Humans with Non-viable Lactobacillus reuteri DSM17648: A Pilot Study. Probiotics Antimicrob Proteins, 2015; 7(2): 91-100.

15. Mehling H, BusjahnA. Non-viable Lactobacillus reuteri DSMZ 17648 (Pylopass ${ }^{\mathrm{TM}}$ ) as a new approach to Helicobacter pylori control in humans. Nutrients, 2013; 5: 3062-3073.

16. Losurdo G, Cubisino R, Barone M, Principi M, Leandro G, Ierardi E, Di Leo A, Probiotic monotherapy and Helicobacter pylori eradication: A systematic review with pooled-data analysis. World J Gastroenterol., 2018; 24(1): 139-149.

17. Wittschier N, Faller G, Hensel A, Aqueous extracts and polysaccharides from Liquorice roots (Glycyrrhiza glabra L) inhibit adhesion of Helicobacter pylori to human gastric mucosa. J Ethnopharmacol., 2009; 125: 218-223.

18. Abadi ATB, Resistance to clarithromycin and gastroenterologist's persistence roles in nomination for Helicobacter pylori as high priority pathogen by World Health Organization. World J Gastroenterol., 2017; 23(35): 6379-6384.

19. Mihai C, Mihai B, Dranga M, Gavrilescu O, Cardoneanu A, Drug V, Cijevschi Prelipcean C, First line Helicobacter pylori eradication in dyspeptic patients. Proceedings. Meeting of the Romanian Society of Neurogastroenterology with Rome IV Regional Central East European Meeting. Neurogastro., 2017: 166-171.

20. De Francesco V, Ridola L, Hassan C, Bellesia A, Alvaro D, Vaira D, Zullo A, Two-week Triple Therapy with either Standard or High-dose Esomeprazole for First-line H. pylori Eradication. J Gastrointestin Liver Dis., 2016; 25: 147-150.

21. Preda CM, Proca D, Sandra I, Fulger LE, Horeanga BK, Manuc M, Manuc T, Dutei CA, Barbu M, Tugui L, Andrei AC, Slavulete BI, Diculescu M, A comparative Study of Efficacy and Safety of Two Eradication Regimens for Helicobacter pylori Infection. Mcedica, 2017; 12(3): 157-163.

22. Arama SS, Tiliscan C, Negoita C, Croitoru A, Arama V, Mihai CM, Pop F, Garg A, Efficacy of 7-Day and 14-Day Triple Therapy Regimens for the Eradication of Helicobacter pylori: A Comparative Study in a Cohort of Romanian Patients. Gastroenterol Res Pract., 2016; 4: 5061640.

23. Li BZ, Threapleton DE, Wang JY, Xu JM, Yuan JQ, Zhang C, Li P, Ye QL, Guo B, Mao C, Ye1 DQ, Comparative effectiveness and tolerance of treatments for Helicobacter pylori: systematic review and network meta-analysis. BMJ, 2015; 351: h4052.

24. Borodin DS, Janov OB, Voinovan JH, The efficacy and safety of probiotic bacteria Lactobacillus reuteri DSMZ17648 in infection with Helicobacter pylori, without absolute indications for eradication therapy: results of the study. The Attending Physician, 2015; 8: www.lvrach.ru.

25. Saggioro A, Caroli M, Pasini M, Bortoluzzi F, Girardi L, Pilone G, Helicobacter pylori eradication with Lactobacillus reuteri. A double-blind-placebocontrolled study. Dig Liver Dis., 2005; 37(Suppl 1): S88, abstr. PO1.49. 
FARMACIA, 2019, Vol. 67, 5

26. Dore MP, Cuccu M, Pes GM, Manca A, Graham DY, Lactobacillus reuteri in the treatment of Helicobacter pylori infection. Intern Emerg Med., 2014; 9: 649-654.

27. Parolova NI, Kornienko EA, Antonov PV, An innovative approach in the treatment of $H$. pylori infection in children. $R M J, 2015 ; 22: 1339-1340$.

28. Dore MP, Soro S, Rocchi C, Loria MF, Bibbò S, Pes GM, Inclusion of Lactobacillus reuteri in the treatment of Helicobacter pylori in Sardinian patients: A case report series. Medicine (Baltimore), 2016; 95(15): e3411: 1-3.
29. Emara MH, Mohamed SY, Abdel-Aziz HR, Lactobacillus reuteri in management of Helicobacter pylori infection in dyspeptic patients: a double-blind placebo-controlled randomized clinical trial. Ther $A d v$ Gastroenterol., 2014; 7(1): 4-13.

30. Laulund S, Commercial aspects of formulation, production and marketing of probiotic products. Human health: The contribution of microorganisms. SpringlerVerlag London 1994. 